\title{
Implementasi Pembelajaran IPS pada Masa Pandemi Covid-19
}

\author{
Laelia Nurpratiwiningsih \\ Universitas Muhadi Setiabudi \\ laelia.np89@gmail.com
}

\begin{abstract}
The Covid 19 pandemic is a big problem for people's lives in the world. The purpose of this study is to find out ips learning in the covid 19 period. One of the highlights in the world of education, where learning activities are carried out online. This learning activity automatically involves teachers and students, as well as parents because learning is done at home. Implementation of learning in rural areas with facilities. This also happened in SD Negeri Ciawi District Banjarharjo Brebes Regency. The method used is a qualitative descriptive survey. Instruments used in the form of interviews are given to learners, teachers and primary school principals. Observations can be used as support in data retrieval. The focus of this study is on learning IPS covid 19. Data analysis techniques use source triangulation. Analyze data by subtracting, viewing and verifying data. The results showed that the covid-19 pandemic had an impact and there were constraints on learning for learners, teachers, and principals. Where learning is done online and offline. With this pandemic all remain vigilant and keep themselves in accordance with health protocols recommended by the government to avoid the coronavirus.
\end{abstract}

Keywords: covid-19, implementation, IPS learning.

\section{Pendahuluan}

Coronavirus dapat menyebabkan hal kurang baik bagi kesehatan. Tanda dan gejala umum yang terjadi, antara lain; gangguan pernapasan, demam, batuk dan sesak napas. Dengan adanya virus ini dapat memberikan dampak pada berbagai bidang. Salah satu yang terkena dampak adalah di bidang pendidikan, baik pada tingkat sekolah maupun perguruan tinggi. Aktivitas pembelajaran yang terjadi dilakukan di rumah. Namun,berkaitan dengan hal tersebut pengetahuan masyarakat terkait dengan Covid 19 masih kurang, hal ini terlihat pada gejala, cara penularan dan pencegahan pada covid 19 (Nasution et al., 2021).

Dampak covid terhadap pendidikan pada jangka pendek adalah adanya kegiatan pembelajaran di rumah. Pembelajaran yang dilakukan di rumah terjadi di lingkungan keluarga desa maupun kota, dimana kegiatan ini belum familiar bagi peserta didik. Permasalahan yang muncul adalah pembelajaran yang awalnya dilakukan tatap muka menjadi pembelajaran jarak jauh, sehingga pelaksanaan pembelajaran berlangsungnya secara online. Peserta didik dan masyarakat belum siap dalam menghadapi era revolusi industry 4.0 ini (Siahaan, 2020).

Pembelajaran online dapat menggunakan beberapa aplikasi. Aplikasi tersebut salah satunya adalah google classroom. Tingkat penerimaan peserta didik terhadap google classroom sangat baik, hal ini sebagai wujud dari platform dalam blended learning. Dalam hal ini berarti peserta didik tertarik dalam penggunaan google classroom (Khairani et al., 2020). Aplikasi ini dapat digunakan bagi sekolah maupun perguruan 
tinggi, yang mana harus disesuaikan dengan kemampuan dari tingkat pendidikan tersebut.

Selain itu, pembelajaran daring dapat dilakukan dengan menggunakan dan memanfaatkan microsoft teams, youtube dan whatsapp. Paltform tersebut dapat dimanfaatkan oleh guru dalam pembelajaran daring. Dimana peserta didik juga dapat melakukan kegiatan pembelajaran secara mandiri ketika di rumah. Penyusunan perangkat pembelajaran oleh tim pengajar juga dibutuhkan dalam mengelola kegiatan pembelajaran (Cahyanto et al., 2021).

Hal ini sejalan dengan Putri (2021) bahwa aplikasi yang digunakan dalam pembelajaran daring antara lain; whatsaap, zoom, google meet, google form. Selain pembelajaran daring, peserta didik dapat melakukan kegiatan pembelajaran luring. Pembelajaran luring dapat dilakukan oleh guru selama pandemic covid dengan menggunakan video pembelajaran dan aplikasi smartphone offline.

Implementasi pembelajaran daring dilakukan pada peserta didik di MTs Negeri Kota Kupang (Yanti \& Alwin, 2021). Kegiatan yang tampak dengan menggunakan beberapa macam aplikasi, RPP dan evaluasi pembelajaran. Namun dalam pelaksanaannya mendapatkan kendala, antara lain kurangnya efektifitas dan efisiensi waktu serta minim akan pemahaman materi. Keadaan tersebut juga terjadi pada peserta didik di SD Negeri Ciawi, dimana peserta didik kurang memahami materi yang sedang diajarkan dan waktu yang digunakan masih kurang.

Penerapan pembelajaran daring dapat dilakukan di sekolah dasar. Penerapan pembelajaran daring yang dilakukan pada kelas III dapat dilakukan dengan menggunakan beberapa jenis aplikasi pembelajaran (Magdalena et al., 2020). Hambatan yang terjadi adalah kurangnya waktu yang digunakan dalam menyampaikan materi pembelajaran dan kurangnya antusias dari peserta didik.

Berkaitan dengan hal tersebut, dapat dikatakan bahwa pendidikan penting bagi keberlangsungan peserta didik dalam memperoleh pembelajaran. Dimana pendidikan merupakan kebutuhan hidup manusia dalam menyiapkan kualitas sumber daya manusia. Kegiatan pembelajaran yang berlangsung secara online maupun tatap muka harus mendapatkan output pembelajaran sesuai dengan yang diinginkan. Sehingga dapat dikatakan pembelajaran tersebut berhasil.

Covid 19 ini merupakan pandemi bagi dunia. Hal ini memberikan banyak dampak bagi kehidupan masyarakat sekitar. Salah satu yang menjadi sorotan adalah pada dunia pendidikan. Dimana kegiatan pembelajaran dilakukan secara daring. Kegiatan pembelajaran ini, otomatis melibatkan guru dan peserta didik. Selain itu, juga melibatkan orang tua karena pembelajaran tersebut dilakukan di rumah. Pelaksanaan pembelajaran tersebut, juga terjadi di daerah pedesaan dengan fasilitas dan sarana seadanya. Hal ini juga terjadi di kecamatan Banjarharjo kabupaten Brebes, yang mana menjadi permasalahan adalah bagaimana implementasi pembelajaran IPS pada masa pandemi covid 19.

Covid 19 memberikan beberapa dampak. Salah satunya adalah jika dilihat dari sudut pandang Ilmu Pengetahuan Sosial (IPS) dapat dikelompokkan pada disiplin ilmu ekonomi, psikologi, politik dan sosiologi. Terlihat keadaan ekonomi di Indonesia menurun. Keadaan politik antara pemerintah pusat dan daerah tidak sinkron. Intensitas pertemuan masyarakat berkurang, jadi kegiatan sosiologis berkurang. Keadaan psikologis masyarakat terganggu, karena terkekang dan selalu berpikir negatif (Oktaviyanti et al., 2020). Pembelajaran IPS ini identik dengan pembelajaran monoton dan hanya mengandalkan kemampuan untuk menghafal. 
Pembelajaran IPS penting bagi kelas tinggi terutama bagi kelas V SD dengan menggunakan pendekatan pembelajaran SAVI (Kurniasih et al., 2021). Hal ini dapat meningkatkan kemampua berpikir bagi pserta didik dalam pembelajaran pada materi IPS. Selain itu pembelajaran IPS juga dapat dilakukan dengan menggunakan metode pembelajaran talking stick ,(Harahap et al., 2019). Dengan adanya metode ini dapat meningkatkan hasil belajar peserta didik.

Psikologi ini merupakan hal yang penting bagi peserta didik. Dimana psikologi ini merupakan ilmu pengetahuan yang mempelajari perilaku, fungsi dan proses mental manusia dengan prosedur ilmiah. Perilaku masyarakat pada saat pandemi menjadi sorotan dalam beraktivitas. Perilaku yang dilakukan oleh orang yang tidak mematuhi kesehatan karena perilaku kognitif (Syah, 2020). Hal ini dikarenakan kemampuan berpikir dalam mengambil keputusan dan penilaiaian.

Perilaku pada pandemi dapat menimbulkan stress. Perubahan kondisi yang terjadi secara tiba-tiba membuat tidak stabil dan tertekan. Maka perlu adanya adaptasi dalam menyesuaikan keadaan yang terjadi, agar tidak terjadi masalah fisik maupun psikologis. Secara psikologis, stres dapat terjadi jika pengetahuan masyarakat terbatas. Keadaan psikologis baik dapat terjadi karena adanya pengetahuan masyarakat yang baik. Pengetahuan masyarakat terkait covid 19 dapat dikatakan baik. Perilaku masyarakat sesuai dengan protokol kesehatan. Oleh karena itu, sebagian besar pada kasus yang terjadi dikatakan rendah (Yantu, 2020).

Kasus lain pada bidang pendidikan adalah pembelajaran yang dilakukan secara tatap muka berubah menjadi pembelajaran online. Hal ini berdampak tidak hanya pada peserta didiknya saja tetapi pada komponen sekolah, seperti; guru dan kepala sekolah. Mau tidak mau sebagai guru dan kepala sekolah mampu mengikuti perkembangan zaman. Dimana mampu beradaptasi terhadap perkembangan ilmu, pengetahuan dan teknologi dalam mengatasi informasi terkait dengan covid $19.90 \%$ tingkat keefektifitasan guru berdampak negatif, hal ini dikarenakan kurang adanya kuota internet dalam pembelajaran daring dan kreativitas guru kurang maksimal (I. T. R. Dewi, 2001).

Anak usia sekolah banyak melihat, mendengar dan mendapatkan informasi berita covid dari televisi. Hal ini dapat menimbulkan stress dan mempengaruhi pola pikir bagi anak jika tidak dipantau dengan baik. Tidak adanya aktivitas membuat keadaan menjadi tidak nyaman. Hal ini dikarenakan pembelajaran dilakukan di rumah. Sehingga bisa menyebabkan anak menjadi jenuh di rumah terus. Interaksi yang terjadi pada peserta didik menjadi terbatas.

Permasalahan-permasalahn yang muncul di kecamatan Banjarharjo, antara lain; pembelajaran yang dilakukan oleh peserta didik di SD dilakukan secara online dan platform yang digunakan dalam pembelajaran terbatas. Selain itu, penelitian ini belum pernah diteliti sehingga menarik untuk diteliti. Dengan adanya permasalahan pendidikan ini dapat memberikan hal yang positif dan negatif dalam pembelajaran. Berkaitan dengan permasalahan tersebut, maka dilakukan penelitian berjudul "Implementasi Pembelajaran IPS pada Masa Covid 19".

\section{Metode}

Metode yang digunakan adalah penelitian kualitatif dengan menggunakan survey. Dimana pembatasan masalah yang akan menjadi objek penelitian. Fokus dalam penelitian ini adalah implementasi pembelajaran pada masa covid 19. Penelitian ini akan memfokuskan pada pembelajaran IPS pada masa covid 19 di SD Negeri Ciawi kecamatan Banjarharjo kabupaten Brebes. Sasaran dalam pendidikan yang 
dimaksudkan ini adalah 6 peserta didik, 6 guru dan kepala sekolah dasar. Maka informan dalam penelitian ini terdapat 13 orang.

Sumber data yang digunakan yaitu data primer dan data sekunder. Data sekunder dalam penelitian ini berupa data jumlah peserta didik anak usia sekolah dasar di SD Negeri Ciawi. Sedangkan data primer dalam penelitian ini didapat dari wawancara, dan observasi. Data yang diperoleh dari 6 peserta didik, 6 guru dan kepala sekolah dasar.

Teknik pengumpulan data diperoleh dari wawancara dan observasi. Wawancara dilakukan untuk memperoleh data mengenai dampak covid 19 pada psikologi dan pendidikan. Observasi dilakukan untuk mengamati pembelajaran IPS di SD Negeri Ciawi kecamatan Banjarharjo kabupaten Brebes. Observasi dapat ditunjukan kepada guru maupun peserta didik.

Uji validitas menggunakan teknik triangulasi, hal ini dilakukan sebagai teknik pemeriksaan data. Triangulasi yang digunakan dalam penelitian ini adalah triangulasi sumber. Data diolah menurut wawancara dan observasi. Langkah-langkah dalam triangulasi data (Moleong, 2010) adalah 1) membandingkan data yang diperoleh dari hasil wawancara dengan berbagai informan, 2) membandingkan berbagai perspektif, pendapat dan pandangan orang lain, dan 3) membandingkan hasil wawancara terkait dengan observasi.

Teknik analisis data melalui proses reduksi data, display data dan verifikasi (Moleong, 2010). Reduksi data diperoleh dari data pemilihan wawancara dari beberapa informan. Selanjutnya display data dilakukan dengan adanya penyajian data yang diperoleh dari ketiga sumber data tersebut dan ditarik kesimpulan. Dimana jawaban yang paling sering muncul dapat dijadikan sebagai verfikasi sesuai dengan permasalahan penelitian yang ada.

\section{Hasil}

Berdasarkan hasil penelitian di SD Negeri Ciawi kecamatan Banjarharjo Kabupaten Brebes dengan metode observasi dan wawancara. Kegiatan penelitian dilakukan pada bulan Juli sampai dengan Desember 2020. Dapat dijelaskan implementasi pembelajaran IPS, dampak dan kendala-kendala dalam pembelajaran IPS pada masa pandemi covid 19 sebagai berikut.

Hasil wawancara dengan Kepala Sekolah, guru dan peserta didik di SD Negeri Ciawi terkait bagaimana implementasi kegiatan pembelajaran IPS pada masa pandemi covid 19 dapat ditunjukkan pada tabel 1.

Tabel 1. Hasil Wawancara terkait Dampak Pandemi Covid terhadap Pembelajaran IPS

\begin{tabular}{ll}
\multicolumn{1}{c}{ IPS } & \multicolumn{1}{c}{ Hasil Wawancara } \\
\hline Informan & Kegiatan pembelajaran yang dilakukan sebagaian besar daring \\
Kepala sekolah & materi dan tugas. Dan setiap 3 hari sekali setiap minggu peserta \\
& didik hadir ke sekolah untuk mengumpulkan tugas. \\
\hline Guru & $\begin{array}{l}\text { Pembelajaran daring dilakukan dengan whatsapp dan setiap satu } \\
\text { minggu 2 kali peserta didik datang ke sekolah. }\end{array}$ \\
\hline Peserta didik & Kegiatan pembelajaran dengan hp dan kadang ke sekolah. \\
\hline
\end{tabular}

Pada tabel 1 menunjukkan bahwa kegiatan pembelajaran yang dilakukan oleh peserta didik menggunakan aplikasi whatsapp dan dibantu dengan pengumpulan tugas setiap 2 kali dalam seminggu. Pembelajaran daring dan luring dilakukan sebagai kebijakan 
sekolah dalam menangani pademi ini agar kegiatan belajar mengajar dapat berjalan dengan baik.

Hasil wawancara dengan kepala sekolah, guru dan peserta didik di SD Negeri Ciawi terkait dampak covid pada kegiatan pembelajaran IPS dapat ditunjukkan pada tabel 2 .

Tabel 2. Hasil Wawancara terkait Dampak Pandemi Covid terhadap Pembelajaran IPS

Informan Hasil Wawancara

Kepala sekolah Covid dapat sangat berdampak pada kegiatan pembelajaran peserta didik, hal ini ditunjukkan pada kegiatan pembelajaran yang sekarang berlangsung dengan menggunakan daring. Dan berdampak pada psikis anak.

Kegiatan belajar mengajar yang tidak efektif karena harus belajar dengan jarak jauh, pencapaian materi yang kurang maksimal dan hal tersebut akan membuat anak menjadi malas untuk belajar.

Sebagai kepala sekolah merasa takut dan bingung, di lain sisi pemerintah menganjurkan sekolah ditutup dan diganti dengan pembelajaran jarak jauh.

Orang tua peserta didik mayoritas adalah petani, yang mana harus berangkat pagi dan ketika pulang ke rumah kebanyakan informan sudah capek sehingga malas untuk melakukan pendampingan belajar terhadap anaknya.

Guru Dampak pandemi covid 19 tak hanya berdampak pada fisik, tetapi juga berdampak pada psikologi peserta didik. Kegiatan pembelajaran peserta didik dilakukan secara daring.

Adanya perbedaan dari tingkah laku, perilaku dan antusias peserta didik dalam proses kegiatan belajar mengajar.

Sehebat dan secanggih apapun perkembangan teknologi yang saat ini ada, tidak akan bisa menggantikan posisi guru atau pengajar untuk mengajarkan atau menyampaikan materi kepada peserta didiknya.

Kegiatan pembelajaran ketinggalan karena sehebat-hebatnya pembelajaran jarak jauh jelas beda jauh dengan pembelajaran tatap muka. Penyampaian materi tidak maksimal

Peserta didik Kegiatan yang berjalan sekarang menggunakan daring. Ke sekolah untuk diberi tugas. Dan di rumah biasanya hanya bermain kalua tidak ada tugas.

Tabel 2 menunjukkan bahwa dampak pandemi ini tak hanya berdampak pada keadaan fisik dan bidang pendidikan, tetapi juga sangat berdampak pada psikologi peserta didik. Jangankan peserta didik, guru-guru lainpun merasa resah akan pandemi Covid-19 ini. Setiap hari ketika informan berada di sekolah atau saat berpergian informan harus mematuhi protokol kesehatan yang dianjurkan pemerintah demi kesehatan orang-orang di sekeliling dan untuk dirinya sendiri.

Covid 19 tidak hanya menyerang kesehatan fisik tetapi juga pada kesehatan psikologis. Keadaan psikologis, seperti; kecemasan, kekhawatiran dan ketakutan. Selain itu, anak merasa jenuh dan bosan dengan situasi dan kondisi yang ada. Kondisi yang terjadi seperti; kesulitan belajar dan gangguan kesehatan mental dapat mempengaruhi lingkungan. Sugesti dalam pikiran berpengaruh terhadap kondisi fisik dan psikis. Jika berpikir negatif maka dapat menimbulkan depresi dan stress.

Kegiatan penutupan sementara bagi sekolah karena adanya covid 19, memberikan dampak bagi pendidikan. Hal ini terlihat pada kegiatan pembelajaran yang dilakukan di rumah. Mau tidak mau aktivitas dilakukan di rumah dengan kemampuan dan fasilitas yang dimiliki. Kemampuan kognitif dan ketrampilan sosial yang terbentuk dari peserta didik dapat dibangun melalui interaksi dengan keluarga. Namun, terjadi 
masalah dikarenakan adanya ketidaksepahaman materi, teknologi dan saran pembelajaran bagi orang tua untuk belajar.

Hasil wawancara dengan Kepala Sekolah, Guru dan Peserta didik di SD Negeri Ciawi terkait kendala-kendala pembelajaran IPS pada masa Pandemi Covid 19 dapat ditunjukkan pada tabel 3 .

Tabel 3. Hasil Wawancara terkait Kendala Pembelajaran IPS pada Masa Pandemi Covid

\begin{tabular}{ll}
\hline \multicolumn{1}{c}{ Informan } & \multicolumn{1}{c}{ Hasil Wawancara } \\
\hline Kepala sekolah & Masih terdapat peserta didik yang tidak mempunyai hp, laptop dan \\
& kuota internet untuk belajar. \\
& Orang tua tidak memahami aplikasi yang digunakan. \\
& Tidak memahami materi dan tugas ynag disampaikan oleh guru. \\
\hline \multirow{3}{*}{ Guru } & Ada beberapa peserta didik tidak mempunyai hp dan laptop. Selain itu, \\
& kuota internet untuk belajar terbatas. \\
& Orang tua dan peserrta didik gaptek tidak paham menggunakannya. \\
& Tugas yang diberikan tidak bsa dikerjakan secara sempurna. \\
\hline Peserta didik & Tidak punya hp dan kuota tidak ada mahal. \\
& Malas untuk belajar, lebih senang bermain. \\
\hline
\end{tabular}

Tabel 3 menunjukkan bahwa hasil wawancara, informan mengatakan bahwa semenjak adanya pandemi Covid-19 dan sekolah ditutup informan terpaksa melakukan kegiatan belajar mengajar secara daring atau secara jarak jauh yang menjadikan informan merasa bosan karena tidak bisa belajar bersama dan bercanda dengan teman-teman. Belum lagi kendala dari peserta didik yang tidak punya hp dan harga kuota yang mahal membuat peserta didik semakin malas. Yang lebih parahnya lagi terkadang peserta didik setelah atau ketika sudah pegang hp, peserta didik malah membuka youtube atau bermain game. Informan juga mengatakan kalau berangkat sekolah hanya dua kali dalam seminggu dan misalpun berangkat informan hanya mengumpulkan tugas dan mendapat tugas baru dari guru yang mana kegiatan tersebut membuat para peserta didik jenuh.

\section{Pembahasan}

Berdasarkan data yang diperoleh dapat ditunjukkan bahwa covid 19 berdampak pada dunia pendidikan. Kegiatan pembelajaran yang dilakukan di SD Negeri Ciawi Banjarharjo adalah dengan menggunakan pembelajaran daring dan luring. Dalam pelaksanaan pembelajaran daring dapat dikatakan cukup lancar. Hal ini terlihat pada adanya aktivitas kegiatan pembelajaran baik secara daring maupun luring. Kegiatan pembelajaran daring dilakukan dengan menggunakan aplikasi whatsapp group. Dimana dengan adanya aplikasi tersebut dapat memberikan materi dan tugas kepada peserta didik. Pembelajaran daring dapat berjalan dengan adanya dukungan dari orang tua masing-masing. Selain itu, pembelajaran luring dilakukan dua kali dalam seminggu. Kegiatan tersebut diberikan dengan cara mengumpulkan tugas yang telah diberikan. Dimana kegiatan ini dibatasi untuk setiap jam dan jumlah dari peserta didiknya.

Pernyataan tersebut seperti pelaksanaan pembelajaran daring yang dilakukan di sekolah dasar dapat dikatakan menyusahkan. Hal ini dapat menyusahkan orang tua dikarenakan anak butuh dampingan dari orang tua (Iqbala \& Sumarni, 2020). Kegiatan pembelajaran dapat berjalan jika terdapat kreativitas dari guru dalam mengajar, sehingga kegiatan yang dilakukan tidak monoton. Jika kreativitas dari guru dapat berjalan dengan maksimal, maka akan menghasilkan pembelajaran yang lebih baik. 
Perencanaan dan pelaksanaan pembelajaran daring dilakukan dengan persiapan matang dan baik. Perencanaan pembelajaran daring dapat dilakukan dengan adanya perangkat keras seperti smartphone, laptop dan kuota. Sedangkan dalam pelaksanaan pembelajaran daring dapat berjalan dengan baik, dengan terjalinnya hubungan sekolah dengan orang tua. Orang tua yang mendukung kegiatan pembelajaran peserta didik dapat membawa dampak pada hasil belajar peserta didik (Septiani \& Ismaya, 2021).

Kebijakan yang dilakukan oleh kepala sekolah SD N Ciawi kecamatan Banjarharjo adalah dengan adanya pembelajaran daring. Kebijakan dalam pembelajaran di rumah memberikan beberapa gangguan. Gangguan tersebut, antara lain; gangguan pembelajaran, penilaian, pembatalan penilaian, peluang mendapatkan pekerjaan dan kualifikasi pekerjaan. Berkaitan dengan hal tersebut Menteri Pendidikan perlu berkoordinasi dengan Menteri terkait lapangan kerja (W. A. F. Dewi, 2020). Hal ini sama dengan penelitian yang dilakukan bahwa covid 19 memberikan dampak pada kegiatan pembelajaran di rumah, proses pembelajaran anak, penilaian pembelajaran di rumah.

Pembelajaran daring memberikan beberapa dampak bagi peserta didik. Hal ini terlihat pada aktivitas belajar peserta didik. Dimana hal ini berdampak pada psikologi pesera didik yang membuat semua menjadi takut dan was-was. Kebiasaankebiasaan yang dulu dilakukan sekarang dihilangkan sementara demi menjaga agar tidak tertular Covid-19. Jaga jarak dilakukan, hal ini dimaksudkan sesuai dengan protokol kesehatan yang ada. Dampak adanya pembelajaran IPS pada masa covid 19 di SD Negeri Ciawi kecamatan Banjarharjo antara lain; pembelajaran dilakukan secara daring, keadaan psikis dari peserta didik menjadi kurang baik, peserta didik malas untuk belajar, peserta didik lebih senang untuk bermain dan suka menonton TV serta materi yang diajarkan kurang memahami.

Kesehatan mental anak menjadi tanggung jawab guru dan kepala sekolah pada saat kegiatan pembelajaran. Jangan sampai hal ini menimbulkan permasalahan bagi anak. Sebagai contoh pandemi mengakibatkan kematian dan penularan yang masif, sehingga hal ini dapat mengganggu kesehatan mental seseorang. Kesehatan mental penting di dunia, namun belum diprioritaskan dalam perlakuannya. Kesehatan ini menjadi bagian integral dalam covid 19 (Ridlo, 2020).

Berdasarkan hasil wawancara dan observasi diperoleh bahwa dampak covid-19 pada pendidikan ini memang sangat berpengaruh sekali. Mulai dari kegiatan belajar mengajar yang tidak efektif karena harus belajar dengan jarak jauh, pencapaian materi yang kurang maksimal dan hal tersebut akan membuat anak menjadi malas untuk belajar di bangku sekolah dasar. Sama halnya dengan di Perguruan Tinggi. Covid 19 berdampak pembelajaran di perguruan tinggi, antara lain; perubahan tatap muka menjadi online, peningkatan dalam penggunaan pembelajaran berteknologi, dan peningkatan kemandirian mahasiswa dalam belajar (Aziz, 2020).

Kendala yang dihadapi ketika melakukan kegiatan pembelajaran IPS adalah tugas yang diberikan tidak mudah untuk dicerna, kuota internet tidak stabil, tidak adanya sarana yang menunjang baik laptop atau hp, aplikasi yang digunakan tidak support dengan $\mathrm{hp}$, orang tua dan peserta didik kurang memahami perkembangan ilmu pengetahuan dan teknologi.

Kendala dalam pembelajaran daring adalah jaringan, perlu adaptasi dalam pembelajaran, lebih fokus pada platform yang digunakan (Ani, 2021). Pada permasalahan penelitian menunjukkan bahwa 5 mahasiswa mengalami kendala dalam jaringan, hal ini dikarenakan rendah signal internet. Peserta didik lebih fokus pada media yang digunakan bukan pada materi yang sedang dibelajarkan. 
Berkaitan dengan hal tersebut berarti bahwa kegiatan pembelajaran yang dilakukan oleh peserta didik di Sekolah Dasar dapat berjalan dengan baik apabila terdapat kerjasama antara guru, peserta didik dan orang tua dalam proses pembelajaran yang dilakukan di rumah. Hal ini sama dengan yang dinyatakan oleh Dewi (2020) bahwa kegiatan pembelajaran daring dapat berjalan cukup baik, hal ini terlihat pada kerjasama pada semua komponen pembelajaran.

\section{Simpulan}

Kesimpulan dari kegiatan penelitian ini adalah bahwa covid 19 menyebabkan dampak dan kendala dalam pembelajaran bagi anak usia Sekolah Dasar. Dimana pembelajaran yang dilakukan menggunakan daring dan luring. Dampak dari pembelajaran daring ada pada keadaan psikologisnya dan sarana dan prasara yang digunakan. Hal ini cukup signifikan terutama berdampak pada psikologis peserta didik dan proses pembelajarannya. Keadaan psikologis terlihat pada rasa cemas, stres dan ketakutan berlebihan yang mengakibatkan panik, sehingga kesehatan mental anak menjadi terganggu. Sedangkan keadaan pendidik terlihat bahwa pembelajaran dilakukan secara jarak jauh. Dimana anak usia sekolah melakukan kegiatan pembelajaran di rumah, dengan bantuan orang tua. Kendala yang dialami oleh peserta didik antara lain; internet tidak stabil, aplikasi tidak mendukung, kurangnya pengetahuan ilmu pengetahuan dan teknologi, tidak ada hp atau laptop.

\section{Saran}

Saran dengan adanya kegiatan pembelajaran pada masa pandemi covid 19 adalah adanya sarana dan prasarana yang mendukung dalam kegiatan pembelajaran di sekolah dasar. Selain itu, perlu adanya perbaikan kesehatan mental bagi peserta didik ketika kembali lagi ke sekolah. Sehingga peserta didik dapat termotivasi untuk belajar lebih giat kembali.

\section{Referensi}

Ani, Y. (2021). Eksplorasi Pembelajaran Daring Mahasiswa PGSD Tingkat Satu Eksplorasi. Jurnal Review Pendidikan Dasar: Jurnal Kajian Pendidikan Dan Hasil Penelitian, 7(2), 69-73.

Aziz, F. (2020). Dampak Covid-19 terhadap Pembelajaran di Perguruan Tinggi. Bioma, $2(1), 14-20$.

Cahyanto, B., Maghfirah, M., \& Hamidah, N. (2021). Implementasi Pembelajaran Daring di Masa Pandemi Covid-19. At-Thullab: Jurnal Pendidikan Guru Madrasah Ibtidaiyah, 5(1).

Dewi, I. T. R. (2001). Dampak Pembelajaran Online Terhadap Efektifitas Mengajar Guru Dimasa Pandemi Covid-19. Journal of the American Chemical Society, 123(10), 2176-2181.

Dewi, W. A. F. (2020). Dampak COVID-19 terhadap Implementasi Pembelajaran Daring di Sekolah Dasar. Edukatif: Jurnal Ilmu Pendidikan, 2(1), 55-61.

Eka Putri, D. P. (2021). Implementasi Pembelajaran Daring dan Luring Saat Pandemi Covid 19. Edugama: Jurnal Kependidikan Dan Sosial Keagamaan, 6(1), 111-130.

Harahap, H. N., Priatna, O. S., \& Nawawi, M. K. (2019). dengan Model Pembelajaran Talking. Jurnal PGSD, 12(2), 79-92.

Iqbala, H. N., \& Sumarni, W. (2020). Implementasi Pembelajaran Daring pada Masa Covid-19 terhadap Perkembangan Anak di Sekolah Dasar. Prosiding Seminar Nasional ..., 973-979.

Khairani, A., Daud, A., \& Adnan, M. (2020). Students' Acceptance of the Use of Google Classroom As a Platform in Blended Learning. AL-ISHLAH: Jurnal Pendidikan, 12(1), 1-16. 
Kurniasih, Q., Nurhasanah, A., \& Hamik, Z. R. (2021). Jurnal PGSD, 11(2), 128-134.

Magdalena, I., Salsabila, A., Krianasari, D., A., \& Apsarini, S., F. (2020). Implementasi Model Pembelajaran Daring pada Masa Pandemi Covid-19 di Kelas IIII SDN Sindangsari III. Jurnal Pendidikan Dan Dakwah, 3(1), 119-128.

Moleong. (2010). Metodologi Penelitian Kualitatif. Remaja Rosda Karya.

Nasution, N. H., Hidayah, A., Sari, K. M., Cahyati, W., Khoiriyah, M., Hasibuan, R. P., Lubis, A. A., \& Siregar, A. Y. (2021). Gambaran Pengetahuan Masyarakat Tentang Pencegahan Covid-19 Kecamatan Padangsidimpuan Batunadua, Kota Padangsidimpuan. Jurnal Biomedika Dan Kesehatan, 4(2), 47-49.

Oktaviyanti, I., Jiwandono, I. S., \& Setiawan, H. (2020). Analisis Persepsi Mahasiswa Pgsd Mengenai Dampak Covid 19 Terhadap Disiplin IlmuSosial. Education and Human Development Journal, 5(2), 70-79.

Ridlo, I. A. (2020). Jurnal Psikologi dan Kesehatan Mental Pandemi COVID-19 dan Tantangan Kebijakan Kesehatan Mental di Indonesia. Departemen Administrasi Dan Kebijakan Kesehatan, Fakultas Kesehatan Masyarakat Universitas Airlangga, 155-164.

Septiani, R., \& Ismaya, E. A. (2021). Implementing Online Learning in The Covid-19 Pandemic. PRIMARY: Jurnal Pendidikan Guru Sekolah Dasar, 10(August), 934941.

Siahaan, M. (2020). Dampak Pandemi Covid-19 Terhadap Dunia Pendidikan. Jurnal Kajian Ilmiah, 1(1), 73-80. https://doi.org/10.31599/jki.v1i1.265

Syah, R. H. (2020). Dampak Covid-19 pada Pendidikan di Indonesia: Sekolah, Keterampilan, dan Proses Pembelajaran. SALAM: Jurnal Sosial Dan Budaya Syar-I, 7(5).

Yanti, S. I., \& Alwin, I. (2021). Implementasi Model Pembelajaran Daring pada Masa Pandemi Covid-19. Jurnal Pendidikan Dan Studi Keislaman, 1(2), 73-84. 